\title{
Vietnam's Development of Human Resources in Science and Technology
}

\author{
M.A Kien, Tran Thi \\ National Agency for Science and Technology \\ 24-26 Ly Thuong Kiet Str, Hanoi, Vietnam
}

\begin{abstract}
In the knowledge-economy era, the quality of human resources has become a key factor in determining a nation's future. Many people agree that improving not only the skill level of individuals but also management practices and the entire human resources system is the prerequisite for the long-term competitiveness and prosperity of a country. Recently, the Government of Vietnam has issued the number of policies to develop human resources in S\&T. Although, Vietnam's human resource in science and technology has increased markedly, both in quality and quantity, making a significant contribution to the development and prosperity of the country, but these policies have not brought the expected results.
\end{abstract}

Keywords: Human resources in science and technology, National Human Resources Development, Vietnam

\section{INTRODUCTION}

The combination of science and technology (S\&T) and human resources (HR) is an important component of competitiveness and economic development, and a means of protecting and enhancing our environment in the coming decades. New technologies are being developed and applied rapidly in many cases. An increasingly skilled workforce will be required if countries are negotiating the rapid changes and new challenges that are emerging in S\&T.

Vietnam's Party and State have paid special attention to the development of human resources in S\&T (HRST). Many HRST development policies of Vietnam has been included in important documents of the Party and State. Especially, this policy has been confirmed in the Decision No. 579/QD-TTg of April 19, 2011: Approving the Strategy on development of Vietnamese human resources during 2011-2020, the Decision No. 418/QD-TTg of April 11, 2012: Approving the Strategy for S\&T development for the 2011-2020 period, the Resolution No. 20-NQ/TW of January 11, 2012 in the sixth meeting of the XI Central Committee of the Communist Party on science and technology development to serve the cause of industrialization and modernization in the socialist orientation economy market and international integration, the Decision No. 40/2014/ND-CP of December 5, 2014: Decree on providing utilization and well treatment of individuals in scientific and technological activities, Decree No. 87/2014/ND-CP dated September 22, 2014, regulation on attracting individuals who are Vietnamese people living abroad and foreign experts to participate in science and technology activities in Vietnam and the Circular No. 24/2015/TT-BLDTBXH dated July 13, 2015 Providing specific provisions on implementation of clause 6 article 14 of the government's Decree No. 87/2014/ND-CP dated September 22, 2014 on interesting Vietnamese expatriates and foreign experts in scientific and technological operations in Vietnam.

\section{BASIC DEFINITION}

\section{A. Human Resources in Science and Technology}

According to Organization for Economic Co-operation and Development (OECD), Human resources in Science and Technology (HRST) of a country/region includes all people who completed education at the third level according to the International Standard Classification of Education (ISCED) (Table 1) in an S\&T field of study and those who have not been formally qualified as above but employed in an S\&T occupation where the above qualifications are normally required. 
Table 1: International Standard Classification of Education (ISCED) 2011and Vietnam's education system corresponding.

\begin{tabular}{|l|l|l|}
\hline Tier & ISCED 2011 (UNESCO) & $\begin{array}{l}\text { The corresponding education level of } \\
\text { Vietnam }\end{array}$ \\
\hline 01 & $\begin{array}{l}\text { Early childhood educational development } \\
\text { Pre-primary education (4-7 years, usually 6 } \\
\text { years) }\end{array}$ & Pre-school education \\
\hline 1 & Primary education (4-7 years, usually 6 years) & Primary education (5 years) \\
\hline 2 & $\begin{array}{l}\text { Lower secondary education (2-5 years, usually 3 } \\
\text { years) }\end{array}$ & Lower secondary education (4 years) \\
\hline 3 & $\begin{array}{l}\text { Upper secondary education (2-5 years, usually 3 } \\
\text { years) }\end{array}$ & $\begin{array}{l}\text { High school (3 years) } \\
\text { Secondary vocational training schools (2-3 } \\
\text { years) } \\
\text { The technical school (2 years) }\end{array}$ \\
\hline 4 & $\begin{array}{l}\text { Post-secondary Non-University education } \\
\text { (Subject to no less than 6 months) }\end{array}$ & $\begin{array}{l}\text { Technical and professional college (3 years) } \\
\text { Vocational college (2 years) }\end{array}$ \\
\hline 5 & Short-cycle tertiary education(2-3 years) & University (bachelor) (4-6 years) \\
\hline 6 & Bachelor's or equivalent level & Master's degree (master's degree) (1-2 years) \\
\hline 7 & Master's or equivalent level (1-3 years) & Ph.D. (3-5 years) \\
\hline 8 & $\begin{array}{l}\text { Doctoral or equivalent level (3 years or more } \\
\text { than 3 years) }\end{array}$ & \begin{tabular}{l} 
Source: Tran DucKhanh (2013), Textbook of Higher Education in Vietnam and the World, Education \\
\hline
\end{tabular}
\end{tabular}

Publishing House, Hanoi

To calculate and analyse HRST, UNESCO assigns S\&T human resources as follows:

The total stock of qualified manpower

\begin{tabular}{|l|l|l|l|}
\hline $\begin{array}{l}\text { Persons who, even though } \\
\text { possessing, the necessary } \\
\text { requisites are outside the labor } \\
\text { market (e.g. housewives, retired } \\
\text { persons) }\end{array}$ & $\begin{array}{l}\text { Persons employed in all the branches of the } \\
\text { economy (except those occupied in S\&T } \\
\text { activities) or actively seeking work. }\end{array}$ & $\begin{array}{l}\text { The total stock } \\
\text { engaged in } \\
\text { S\&T activities }\end{array}$ & $\begin{array}{l}\text { The total } \\
\text { stock } \\
\text { engaged in } \\
\text { R\&D } \\
\text { activities }\end{array}$ \\
\hline
\end{tabular}

Figure 1: Total workforce with qualifications

Source: UNESCO (1984), Manual for Statistics on Scientific and Technological Activities, Division of Statistics on Science and Technology, Office of Statistics.

S\&T human resources are one of the important indicators to compare S\&T resources of other countries, especially the one on R\&D personnel. 


\section{B. The definition of $R \& D$ personnel}

According to the OECD, R\&D personnel in a statistical unit include all persons engaged directly in R\&D, whether employed by the statistical unit or external contributors fully integrated into the statistical unit's R\&D activities, as well as those providing direct services for the R\&D activities (such as R\&D managers, administrators, technicians, and clerical staff)[ Frascati, 2015].
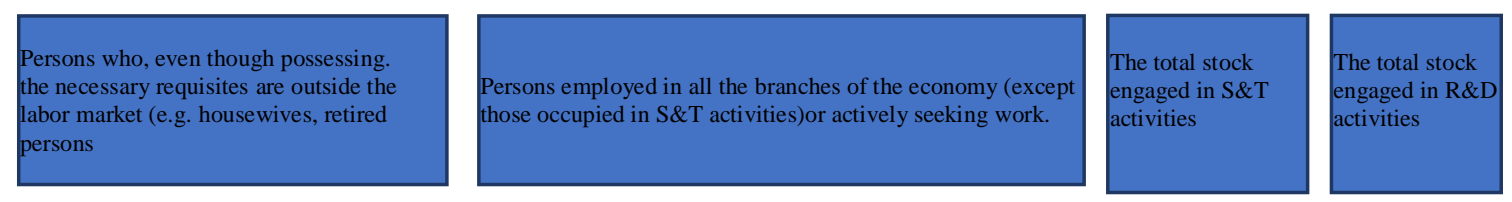

R\&D personnel can be classified into 3 groups:

Researchers:are professional staff with college/university, master's and doctoral degrees or do not have an official degree but do the same work as a researcher/scientist involved in the process of creating new knowledge, products, and processes, creating new methods and systems.

Technicians and equivalent staff are persons whose main tasks require technical knowledge and experience in one or more fields of engineering, the physical and life sciences, or the social sciences, humanities, and the arts. They participate in R\&D by performing scientific and technical tasks involving the application of concepts and operational methods and the use of research equipment, normally under the supervision of researchers.

Other supporting staff includes skilled and unskilled craftsmen, and administrative, secretarial, and clerical staff participating in R\&D projects or directly associated with such projects.

\section{VIETNAM'S R\&D PERSONNEL}

In the National R\&D Survey being conducted by the Ministry of Science and Technology, R\&D personnel who should be calculated included:

- At R\&D organizations ( $R \& D$ institutes and centers): all employees of the organization (excluding the employees exclusively working in the manufacturing or business units(if any) and not participating in $R \& D$ activities of the organization);

- At universities, academies and colleges: all lecturers and staffs with bachelor degrees and above working at $R \& D$ units of the university, excluding staff who only perform the support to teaching work (for example academic administration executives...);

- At administrative and non-business governmental organizations implementing R\&D activities (i.e. R\&D projects, programs): only the staffs who directly participatee in the R\&D projects or programs;

- At business enterprises, $R \& D$ personnel only includes staffs working at units dedicated to $R \& D$, technology and product development(it means that not all technical staffs of the enterprises are calculated).

\section{A. Total National R\&D personnel}

According to the aggregated results of the 2018 National R\&D survey, in 2017, 172,683 staffs were participating in R\&D activities, an increase of about 5,000 people (nearly 3\%) compared to the previous two years. Based on occupation, the number of researchers accounts for $78.8 \%$, while techniciansare only $6.4 \%$, support staff accounts for nearly $15 \%$. In the past 8 years, the number of R\&D personnel in Vietnam has increased significantly (nearly 31,000 people, an increase of nearly $27 \%$ ), but the structure is relatively stable with the researchers account for $78 \%$, the technicians account for 6-7\%, and the rest are support staff (Table 1). 
Table 1. Total National R\&D personnel over the years

\begin{tabular}{|l|r|r|r|r|r|r|r|r|}
\hline \multirow{2}{*}{$\begin{array}{l}\text { R\&D personnel } \\
\text { by occupation }\end{array}$} & \multicolumn{2}{|c|}{$\mathbf{2 0 1 1}$} & \multicolumn{2}{|c|}{$\mathbf{2 0 1 3}$} & \multicolumn{2}{c|}{$\mathbf{2 0 1 5}$} & \multicolumn{2}{c|}{$\mathbf{2 0 1 7}$} \\
\cline { 2 - 9 } & headcounts & Ratio & headcounts & Ratio & headcounts & Ratio & headcounts & Ratio \\
\hline - Researchers & 105.230 & 78,08 & 128.997 & 78,30 & 131.045 & 78,12 & 136.070 & 78,80 \\
\hline - Technicians & 9.781 & 7,26 & 12.799 & 7,77 & 11.522 & 6,87 & 11.066 & 6,41 \\
\hline - Supporting staffs & 19.770 & 14,66 & 22.948 & 13,93 & 24.179 & 15,01 & 25.547 & 14,79 \\
\hline $\begin{array}{l}\text { Total R\&D } \\
\text { personnel }\end{array}$ & $\mathbf{1 3 4 . 7 8 1}$ & $\mathbf{1 0 0}$ & $\mathbf{1 6 4 . 7 4 4}$ & $\mathbf{1 0 0}$ & $\mathbf{1 6 7 . 7 4 6}$ & $\mathbf{1 0 0}$ & $\mathbf{1 7 2 . 6 8 3}$ & $\mathbf{1 0 0}$ \\
\hline
\end{tabular}

Source: National R\&D Survey, National Agency for Science and Technology Information.

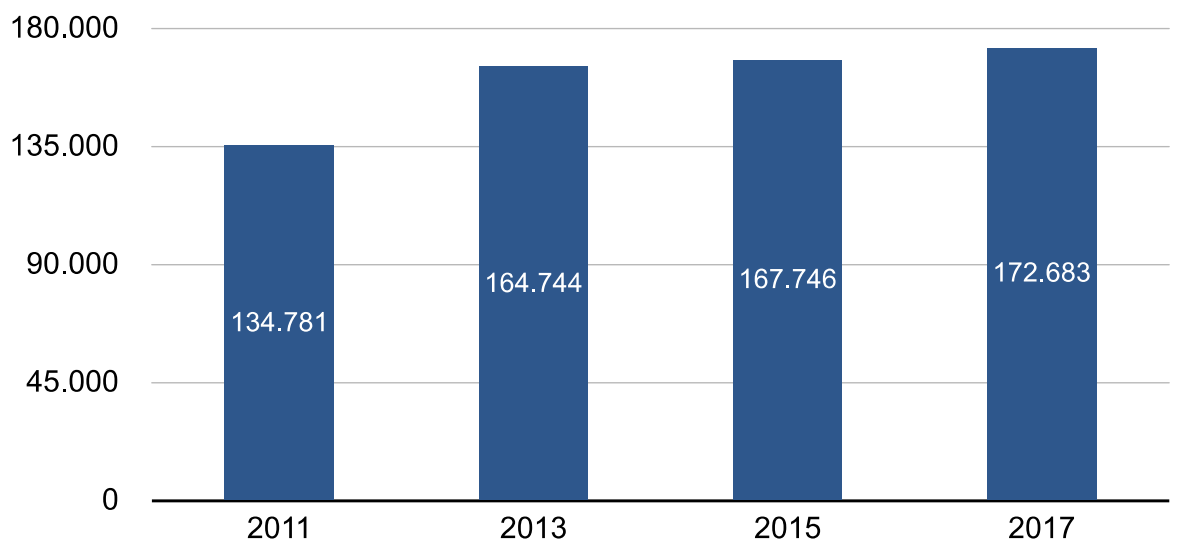

Figure 1.Total National R\&D personnel over the years

Source: National R\&D Survey, National Agency for Science and Technology Information.

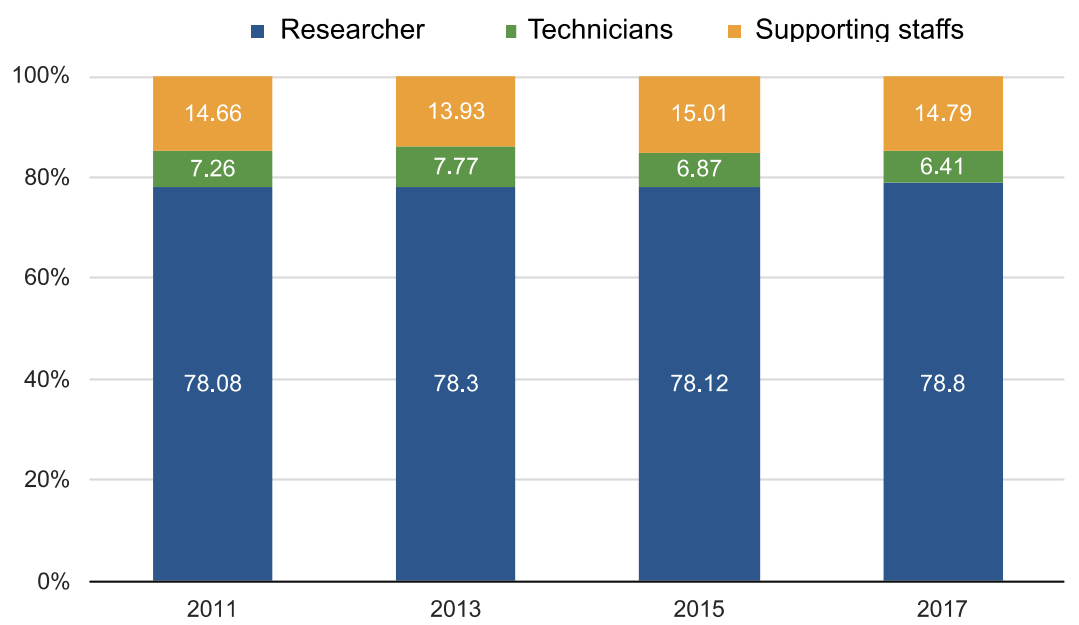

Figure 2. R\&D personnel of Vietnam by occupation

Source: National $R \& D$ Survey, National Agency for Science and Technology Information.

According to a sector of performance, R\&D personnel is concentrated in higher education institutions, accounting for $51.25 \%$, followed by $R \& D$ institutes with $19.8 \%$. R\&D personnel in the enterprise sector only 
account for $15.2 \%$. Details of the distribution of R\&D staff by sector of performance and occupation are shown in Table 2.

Table 2. R\&D personnel by sector of performance and occupation, 2017(headcounts)

\begin{tabular}{|l|c|c|c|c|}
\hline \multirow{2}{*}{\multicolumn{1}{c|}{ Sector }} & \multirow{2}{*}{ Total } & \multicolumn{3}{c|}{ Occupation } \\
\cline { 3 - 5 } & & \multirow{2}{*}{ Researchers } & Technicians & \multirow{2}{*}{ Supporting staffs } \\
\hline R\&D institutes & 34.197 & 26.681 & 2.406 & 5.110 \\
\hline Higher education institutions & 88.481 & 69.095 & 2.981 & 16.405 \\
\hline S\&T service organization & 3.229 & 2.331 & 442 & 456 \\
\hline State administrative organizations & 20.584 & 14.949 & 3.148 & 2.487 \\
\hline Enterprises & 26.192 & 23.014 & 2.089 & 1.089 \\
\hline Total & $\mathbf{1 7 2 . 6 8 3}$ & $\mathbf{1 3 6 . 0 7 0}$ & $\mathbf{1 1 . 0 6 6}$ & $\mathbf{2 5 . 5 4 7}$ \\
\hline
\end{tabular}

Source: National R\&D Survey, National Agency for Science and Technology Information.

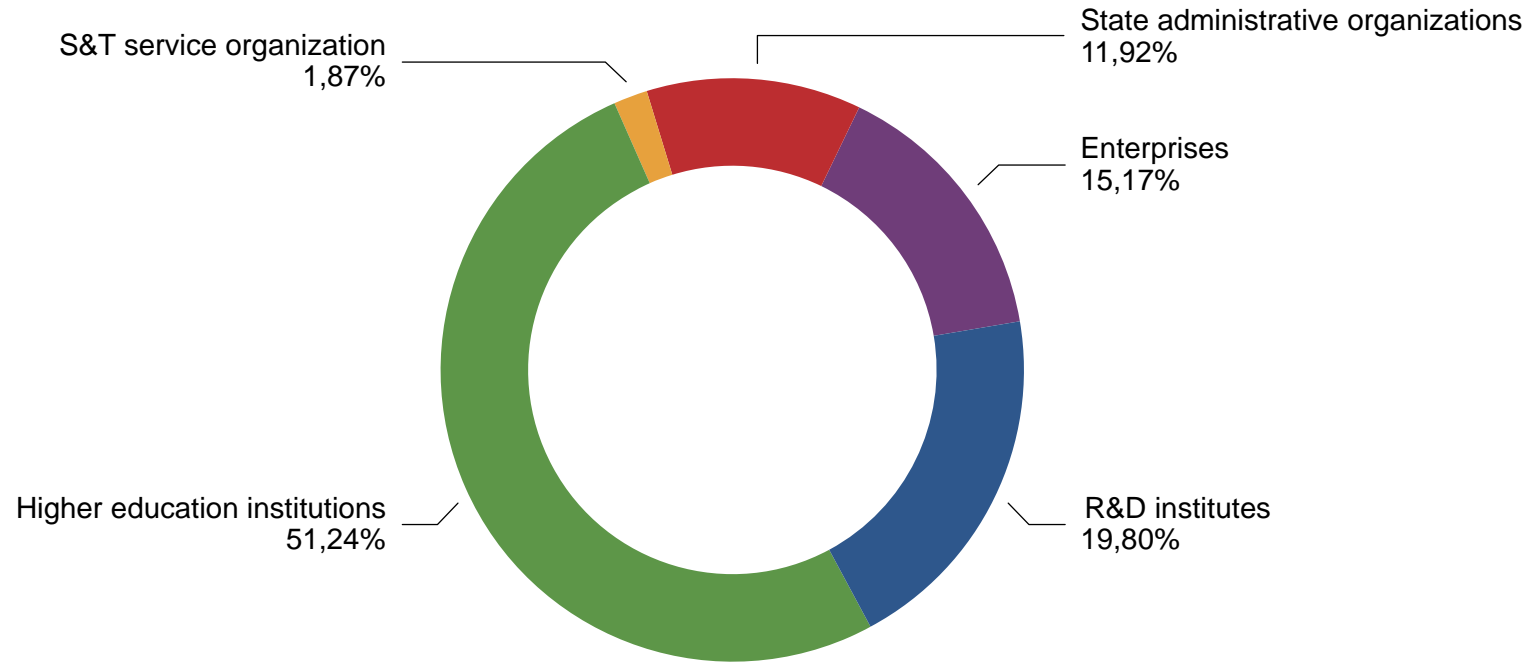

Figure 3. R\&D personnel by sector of performance

Source: Research and Development, National Department of Science and Technology Information.

\section{B. Researchers}

According to OECD methodology, researchers are R\&D personnel holding bachelor's, master's and doctor's degrees, and spending at least $10 \%$ of their working hours on R\&D activities. The number of researchers in Vietnam is presented in Table 3.

Table 3. Researchers by qualification (headcounts)

\begin{tabular}{|c|c|c|c|c|}
\hline Qualification & 2011 & 2013 & 2015 & 2017 \\
\hline Doctor & 11.501 & 12.261 & 14.376 & 15.874 \\
\hline Master & 34.618 & 45.224 & 51.128 & 55.890 \\
\hline University & 55.116 & 66.684 & 60.719 & 57.022 \\
\hline College & 3.995 & 4.828 & 4.822 & 7.284 \\
\hline Total & 105.230 & 128.997 & 131.045 & 136.070 \\
\hline
\end{tabular}

Source: Research and Development, National Department of Science and Technology Information. 
Over the years, the number and qualifications of the researchers have improved. The proportion of researchers with postgraduate degrees (doctoral and master's degrees) in the total number of researchers has increased from 43.8\% (2011) to 52.7\% (2017) (Table 3). However, the proportion of highly qualified researchers (doctoral) is still low, only about $11.67 \%$ and not much increase compared to previous years.

The survey results show that the number of researchers in higher education institutions, with more than 69,000 people, accounts for more than half of the total number of researchers in Vietnam. From 2013 - 2017, the qualifications of the researchers in this area have improved significantly, the number of PhDs increased by $33.4 \%$ from nearly 8,000 to over 10,600 people. Second is the number of researchers working in R\&D institutes (26,681 people), equal to nearly $20 \%$ of the total. The enterprise sector has over 23 thousand people, accounting for nearly $17 \%$. The administrative and non-business sector also has a fairly large number of researchers (about $11 \%$ of the total). In R\&D institutes and universities, researchers with doctoral degrees account for more than $15 \%$, in S\&T administrative, career and service organizations 5.8\% and 5, respectively. $2 \%$. In enterprises, only about $1 \%$ of researchers has a doctorate.

In particular, the number of researchers in $R \& D$ organizations in recent years tended to decrease, from 29,820 people in 2013 to 26,681 people in 2017 . In which, the number of highly qualified staff (doctorates, masters) is still increasing, but the number of researchers with university and college degrees has decreased significantly. The number of researchers with doctoral degrees in State administrative organizations increased by nearly $80 \%$ between 2013 and 2017, while the number with a university degree decreased by nearly $30 \%$ (Table 4). This is the result of the process of restructuring, streamlining the team, improving the autonomy of S\&T non-business units.

Table 4. Researchers by qualification and sector of performance (headcounts)

\begin{tabular}{|c|c|c|c|c|}
\hline Sector & Researchers & 2013 & 2015 & 2017 \\
\hline \multirow{5}{*}{ R\&D institutes } & Doctor & 3.367 & 3.781 & 4.029 \\
\hline & Master & 8.815 & 9.405 & 9.261 \\
\hline & University & 16.635 & 15.661 & 12.694 \\
\hline & College & 1.002 & 939 & 697 \\
\hline & Total & 29.819 & 29.786 & 26.681 \\
\hline \multirow{5}{*}{ Higher education institutions } & Doctor & 7.959 & 9.624 & 10.619 \\
\hline & Master & 31.582 & 35.922 & 40.011 \\
\hline & University & 22.819 & 19.279 & 17.624 \\
\hline & College & 1.075 & 803 & 841 \\
\hline & Total & 63.435 & 65.628 & 69.095 \\
\hline \multirow{5}{*}{ Enterprises } & Doctor & 185 & 205 & 239 \\
\hline & Master & 1.154 & 1.231 & 1.293 \\
\hline & University & 15.175 & 15.876 & 17.126 \\
\hline & College & 2.039 & 2.150 & 4.356 \\
\hline & Total & 18.553 & 19.462 & 23.014 \\
\hline \multirow{5}{*}{ State administrative organizations } & Doctor & 481 & 695 & 865 \\
\hline & Master & 3.411 & 3.932 & 4.718 \\
\hline & University & 11.403 & 8.296 & 8.069 \\
\hline & College & 659 & 829 & 1.297 \\
\hline & Total & 15.954 & 13.752 & 14.949 \\
\hline \multirow{2}{*}{ S\&T service organization } & Doctor & 269 & 71 & 122 \\
\hline & Master & 260 & 638 & 607 \\
\hline
\end{tabular}




\begin{tabular}{|l|l|r|r|r|}
\hline Sector & Researchers & $\mathbf{2 0 1 3}$ & \multicolumn{1}{|c|}{$\mathbf{2 0 1 5}$} & \multicolumn{1}{|c|}{$\mathbf{2 0 1 7}$} \\
\hline \multirow{5}{*}{} & University & 652 & 1.607 & 1.509 \\
\cline { 2 - 5 } & College & 53 & 101 & 93 \\
\cline { 2 - 5 } & Total & $\mathbf{1 . 2 3 4} *$ & $\mathbf{2 . 4 1 7}$ & $\mathbf{2 . 3 3 1}$ \\
\hline
\end{tabular}

* Researchers in non-profit organizations.

Source: Research and Development, National Department of Science and Technology Information.

Figure 4 and Figure 5 describes the distribution of the researchers by sector of performance and by S\&T field in 2017. This percentage has not changed much compared to 2015 with about $1 / 3$ of researchers in the fields of science, technique, and technology (34.3\%) as much as the number of researchers in the field of social science $(33.4 \%)$. The remaining one-third is the number of researchers divided equally among three fields of health, natural science, and Agricultural sciences.

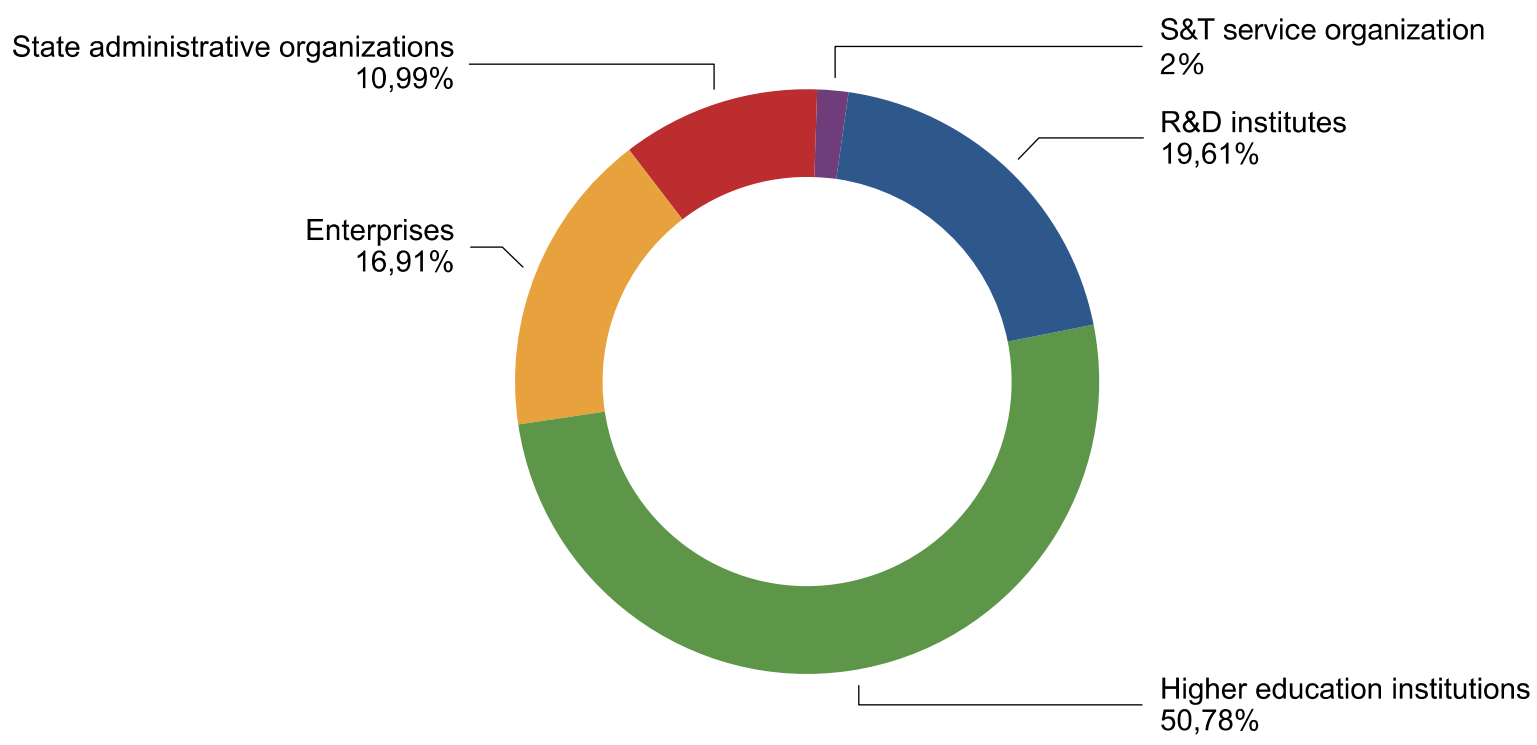

Figure 4. Researchers by sector of performance

Source: Research and Development, National Department of Science and Technology Information.

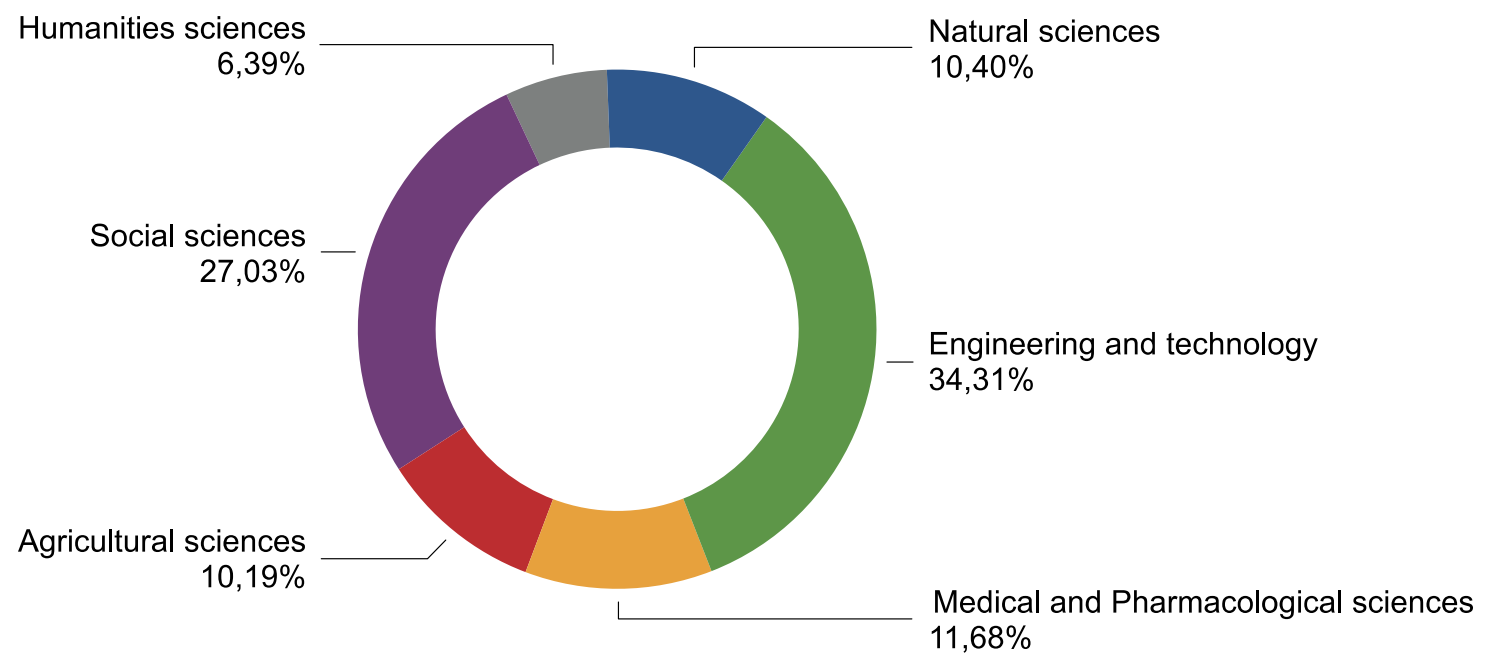

Figure 5. Researchers by S\&T field in 2017 
Source: Research and Development, National Department of Science and Technology Information.

Table 5. Researchers by S\&T fields andsector of performance, 2017(headcounts)

\begin{tabular}{|c|c|c|c|c|c|c|}
\hline \multirow[b]{2}{*}{ S\&T Field } & \multirow[b]{2}{*}{ Total } & \multicolumn{5}{|c|}{ Sector of performance } \\
\hline & & $\begin{array}{c}\text { R\&DInstit } \\
\text { utes }\end{array}$ & University & $\begin{array}{c}\text { State } \\
\text { administrative } \\
\text { organizations }\end{array}$ & $\begin{array}{c}\text { S\&T } \\
\text { service } \\
\text { organizatio } \\
n\end{array}$ & Enterprises \\
\hline Natural sciences & 14.155 & 3.784 & 8.829 & 1.274 & 268 & \\
\hline Engineering and technology & 46.685 & 8.993 & 18.283 & 1.971 & 619 & 16.819 \\
\hline $\begin{array}{l}\text { Medical and Pharmacological } \\
\text { sciences }\end{array}$ & 15.894 & 1.873 & 7.374 & 6.284 & 363 & - \\
\hline Agricultural sciences & 13.860 & 5.503 & 5.154 & 2.127 & 857 & 219 \\
\hline Social sciences & 36.785 & 5.545 & 22.363 & 2.767 & 218 & 5.892 \\
\hline Humanities sciences & 8.691 & 983 & 7.092 & 526 & 6 & 84 \\
\hline Total & 136.070 & 26.681 & 69.095 & 14.949 & 2.331 & 23.014 \\
\hline
\end{tabular}

Source: Research and Development, National Department of Science and Technology Information.

\section{Vietnam's policies for HRST}

\section{A. Policies for HRST in general}

Policies for HRST are related to recruitment, training; salary and income; honor and reward.

Regarding recruitment, there are 2 forms of payroll and contract, in which the number of payrolls is decided by the superior management agency in terms of quantity as well as the form of examination. However, the expansion of contractual recruitment on the side of payroll has created opportunities for organizations to recruit young and talented scientists without having to wait for payroll when the number of staff members is limited. Employees recruited under a contractual mechanism are equal to permanent employees in job creation, insurance premiums, opportunities, and other benefits.

In terms of training, in recent years, Vietnam's State has paid great attention to the development of human resources through expanding postgraduate training domestically and abroad, especially the program of sending staff to train abroad such as Program $322^{1}$, Program $165^{2}$, Program $911^{3}$ and many other programs ${ }^{4}$. Through these programs, the number of staff with master's and doctoral degrees has increased significantly. In addition, there are many bilateral cooperation training programs, joint training programs, and foreign language training programs that have created conditions for HRST to have opportunities to study to improve their qualifications.

Regarding salary, it is uniformly applied according to the State's general salary scale and table for each research category. From 2003 up to now, the common minimum wage has been adjusted 10 times, from VND 21 million to VND 1,150,000. However, there is no breakthrough policy on salary and in fact, has not solved the issue of income for HRST.

\footnotetext{
${ }^{1}$ Decision No. 322/QD-TTg of the Prime Minister of Government, dated April 19, 2000, approving the project on "training scientific and technical cadres at foreign establishments with the state budget."

${ }^{2}$ Announcement No. 165-TB/TW dated June 27, 2008, of the Politburo on the project "Training and retraining for leaders and managers overseas under the state budget."

${ }^{3}$ Decision No. 991-QD-TTg dated June 17, 2010, approving the scheme on "Doctoral Training for university and college lecturers during 2010-2020"

${ }^{4}$ Decision No. 1558/QD-TTg dated August 18, 2010, approving the scheme on "Training and developing of human resources in the field of atomic energy"; Decision No. 698/QĐ-TTg dated June 1, 2009, approving the overall plan on development of information technology human resources up to 2015 and orientations toward $2020 \ldots$
} 
Regarding the reward and honor, in addition to Ho Chi Minh Awards and State Awards, there are many other awards for HRST such as the VIFOTEC Award, the Vietnam Young Science Talent Award, and the Golden Globe Award, Vietnam Talent Award, Ta QuangBuu Prize, Tran Dai Nghia Prize, ... These awards are periodically awarded and have contributed to honor talented scientists.

\section{B. Policies for high-quality S\&T human resources}

Recently, Vietnam'sParty and State have issued a few guidelines and policies on developing high-quality human resources as follow:

- Decree No. 40/2014 /ND-CP dated 1 May 2, 2014, of the Government on providing utilization and well treatment of individuals in scientific and technological activities details and guides the implementation of Articles 19, 22 and 23 of the Law on Science and Technology regarding scientific research titles, technological titles, training of human resources and fostering of talents in science and technology, incentives for the use of human resources and talents for science and technology.

- Decree No. 87/2014/ND-CP of September 22, 2014, of the Governmenton attracting individuals who are Vietnamese people living abroad and foreign experts to participate in science and technology activities in Vietnam

- Decree No. 27/2020/NĐ-CP dated 1/3/2020 Amending and supplementing a number of articles of Decree No. 40/2014 / ND-CP dated May 12, 2014, of the Government regulating the use of Utilizing individuals for science and technology activities and the Government's Decree No. 87/2014/ND-CP dated September 22, 2014, providing for the attraction of individuals engaged in science and technology activities who are overseas Vietnamese and foreign experts participating in science and technology activities in Vietnam.

- Circular No. 24/2015/TT-BLDTBXH dated July 13, 2015, of the Ministry of Labour, War Invalids and Social Affairs providing specific provisions on implementation of clause 6 article 14 of the government's decree no. 87/2014/ND-CP dated September 22, 2014, on interesting Vietnamese expatriates and foreign experts in scientific and technological operations in Vietnam. This Circular provides for the simplified process and procedure for issuance of work permits to Vietnamese expatriates and foreign experts getting involved in carrying out scientific and technological operations in Vietnam as stipulated in Clause 6 Article 14 enshrined in the Decree No. 87/2014/ND-CP.

\section{CONCLUSION}

To catch up with the trend that the role of science and technology is increasingly important for the development of the economy, both developed and developing countries have focused on developing HRST. meeting the requirements of building an economy based on theinnovation of science and technology. To achieve this, countries need to develop a strong contingent of HRST with experienced leading researchers, capable of leading and organizing public, large-scale research and development projects, aiming to create technologies and products with breakthrough results.

In Vietnam, after more than 20 years of implementing the Resolution of the 3rd session of the VIII Party Central Committee on "strategy on cadres in the period of accelerating industrialization and modernization of the country", HRST has made significant progress, constantly increasing in quantity and quality, maturing in all aspects, step by step standardized, rejuvenated and, adaptable to the task in the new stage and make an important contribution to the cause of national construction and defense.

According to the statistics of the Ministry of Science and Technology, in 2019, the whole country had more than 136,000 researchers with increasingly advanced qualifications (the number of staff with a doctorate and master's degrees accounts for $52.7 \%$ of the research force). Such results are due to the fact that Vietnam's Party and State have issued a series of documents on training, attracting and using high-quality human resources. However, these policies are still separated, uncomprehensive systematic. The policies on training, attracting and using HRST in general and HRST with high qualificationsin particularneed to be concretized.

To be able to solve these problems, several solutions to train, attract and use HRST in the coming time are recommended as follows:

\section{Thelong-term demand for HRSTneeds to be forecasted.}

Forecasting HRST in the long term to calculate the required number of HRST. Once the demand for HRST has been identified, it will help policy-makers and managers identify tasks and solutions that need to be performed to achieve the set goals, including key solutions for training and attracting HRST. In other words, the 
forecast for HRST demand will provide input for policymakers in proposing policies for developing HRST in general and highly qualified S\&T human resources in particular.

Solutions for training:

- Promote the training of HRST in the priority technology fields at home and abroad;

- Supporting young scientists to perform potential S\&T tasks to create a source of developing highly qualified HRST;

- Develop and implement a program to select and foster a contingent of talented HRST;

- Create a competitive environment for young talents to develop and show their competencies.

Solutions to attracting HRST:

- Formulate and implement a policy of appreciation and treatment, especially in terms of material and spirit, to attract talents;

- To formulate and implement policies to encourage and support HRST with high qualifications of overseas Vietnamese and foreigners participating in S\&T activities in the country;

Solutions for using HRST:

- Using a contingent of leading scientists and leading scientists to lead and develop strong HRST;

- Invest in new construction and upgrade a number of existing S\&T organizations according to the model of high-end research institutes and excellent research centers to create a favorable working environment and promote the creative capacity of the labor force. science and technology activities;

- Select and assign appropriate tasks for HRST and have a timely reward policy, enjoy worthy benefits with the value of creative labor to encourage them to promote their creative capacity and dedication. Delegate full initiative to leading scientists in the organization and implementation of the assigned S\&T tasks.

\section{REFERENCES}

[1] Ho Ngoc Luat (2017), "S\&T Human Resources: from the concept of international organizations to the applicability to Vietnam”,Journal of Information and Documentation, 1917,Vol 1, p. 15-24.

[2] National Institute for Science and Technology Policy and Strategy Studies (2013), Research on theoretical and practical bases to develop policies to train, attract and use highly qualified S\&T human resources in Vietnam until 2020.

[3] Ministry of Science and Technology (2013), the 2013 Vietnam's Science and Technology, Science and Technology, Publishing House.

[4] Ministry of Science and Technology (2019), the 2019 Vietnam Science, Technology and Innovation, Science and Technology, Publishing House.

[5] National Agencyfor Science and Technology Information (2015), Research and application of OECD methodologies in determining the criteria of full time equivalent human resources (FTE).

[6] OECD (1995), The measurement of scientific and technological activities manual on the measurement of human resources devoted to $S \& T$ "Canberra Manual", Paris: OECD Publishing.

[7] OECD(2015), Frascati Manual 2015: Guidelines for Collecting and Reporting Data on Research and Experimental $l$ Development, Paris:OECD Publishing.

[8] PhanXuan Dung (2018), "Developing S\&T human resources to meet current requirements", State Organization Magazine, 2018, No. 5 , pages 8-14.

[9] Tran DucKhanh (2013), Textbook of Higher Education in Vietnam and the World, Education Publishing House, Hanoi.

[10] UNESCO (1984), Manual for Statistics on Scientific and Technological Activities, Division of Statistics on Science and Technology, Office of Statistics. 